\title{
HHLA2 Gene
}

National Cancer Institute

\section{Source}

National Cancer Institute. HHLA2 Gene. NCI Thesaurus. Code C156392.

This gene plays a role in the modulation of T-cell activation. 